\title{
Subarachnoid and Intracerebral Hemorrhage After Alcohol Ingestion and Illicit Use of Sildenafil
}

\author{
Reçetesiz Sildenafil ile Alkol Kullanım Sonrası Gelişen Subaraknoid \\ Kanama ve Intraserebral Hematom
}

\author{
Veysel ANTAR, Neslihan Hatice KOKSAL SUTPIDELER, Oguz BARAN, Gorkem BITIRAK \\ Istanbul Research and Education Hospital, Department of Neurosurgery, Istanbul, Turkey
}

Corresponding Author: Veysel ANTAR / E-mail: veyselantar@hotmail.com

\begin{abstract}
Sildenafil is a drug used in the treatment of male impotence. Few cases of spontaneous intracerebral hemorrhage following the use of sildenafil have been cited in the literature. A 42-year-old man was admitted to the emergency outpatient clinic of İstanbul Educational and Research Hospital after sudden loss of consciousness. He had ingested alcohol, taken $50 \mathrm{mg}$ sildenafil and had sexual intercourse. Non-contrast cranial tomography revealed an intracerebral hematoma with extension to the ventricles.

Sildenafil is a selective phosphodiesterase- 5 enzyme inhibitor. With the inhibition of PDE-5, the amount of cyclic-guanosine monophosphate (c-GMP) in the smooth vascular muscle cells in the corpus cavernosum increases, leading to a relaxation of muscles and vasodilatation. Studies have shown that the NO-c-GMP pathway leads to cerebral vasodilatation with a similar mechanism. The literature has shown that the effect of PDE-1 and PDE-2 on cerebral bleeding control is affected by sildenafil. This increased blood flow increases the risk of intracranial haemorrhage.

Although data concerning the presentation of intracerebral hematoma in connection with the combined use of alcohol ingestion and use of sildenafil is inadequate, it can nevertheless be thought that the combined use increases the risk of spontaneous intracerebral hemorrhage and caution is in order concerning the matter.
\end{abstract}

KEYWORDS: Sildenafil, Intracerebral, Hemorrhage, Alcohol, Subarachnoid bleeding

öz

Sildenafil erkek impotansının tedavisinde kullanılan bir ilaçtır. Sayısı az olsa da literatürde sildenafil kullanımı sonrasında spontan intraserebral hemoraji olguları bildirilmiştir. Kırk iki yaşında bir erkek hasta ani bilinç kaybı sonrasında İstanbul Eğitim ve Araştırma Hastanesinin acil polikliniğine başvurdu. Alkol alıp, 50mg sildenafil kullanmış ve cinsel ilişkide bulunmuştu. Kontrastsız kraniyal tomografi ventriküllere uzanan bir intraserebral hematom gösterdi.

Sildenafil selektif bir fosfodiesteraz-5 enzim inhibitörüdür. PDE-5 inhibisyonu ile korpus kavernosumdaki düz vasküler kas hücrelerinde siklik guanozin monofosfat (c-GMP) miktarı artıp kaslarda gevşeme ve vazodilatasyona yol açar. Çalışmalar NO-c-GMP yolağının benzer bir mekanizmayla serebral vazodilatasyona yol açtığını göstermiştir. Literatür, PDE-1 ve PDE-2'nin serebral kanama kontrolü üzerindeki etkisinin sildenafilden etkilendiğini göstermiştir. Bu artmış kan akışı, intrakraniyal kanama riskini artırır.

Kombine alkol alma ve sildenafil kullanmayla bağlantılı olarak intraserebral hematom ortaya çıkmasıyla ilgili veriler yetersiz olsa da kombine kullanımın spontan intraserebral kanama riskini artırdığı ve bu konuda dikkatli olmak gerektiğini düşünülebilir.

ANAHTAR SÖZCÜKLER: Sildenafil, İntraserebral, Kanama, Alkol, Subaraknoid kanama

\section{INTRODUCTION}

Sildenafil is a drug used in the treatment of male impotence. It has a direct effect on the vessels of the corpus cavernosum. Sildenafil acts on the corpus cavernosum by way of a raised concentration of c-GMP and NO in the smooth muscle cells. The increased c-GMP concentration leads to vasodilatation and the erection of the penis (7). In addition to this vascular reaction, other well-known side effects are flushing, headache and dizziness due to dilatation of the cerebral veins (10). Among its adverse effects, hemorrhagic stroke has not been widely reported yet (7). Although few cases of spontaneous intracranial hemorrhage following the use of sildenafil have been reported in the literature. We report a case of fatal subarachnoid and intracerebral haemorrhage as a result of ingestion of alcohol and non-prescription use of sildenafil.

\section{CASE REPORT}

A 42-year-old man was admitted to the emergency outpatient clinic of İstanbul Educational and Research Hospital after sudden loss of consciousness. He was said to have ingested alcohol, taken $50 \mathrm{mg}$ sildenafil and had sexual intercourse. On admission, blood pressure was $210 / 130 \mathrm{~mm} \mathrm{Hg}$ and pulse 88 per minute. The Glasgow Coma Scale score was 5 (no eye opening, no verbal response and flexion to pain). Non-contrast cranial tomography revealed an anterior interhemispheric bleeding with extension to all four ventricles (Figure1, 2). An 


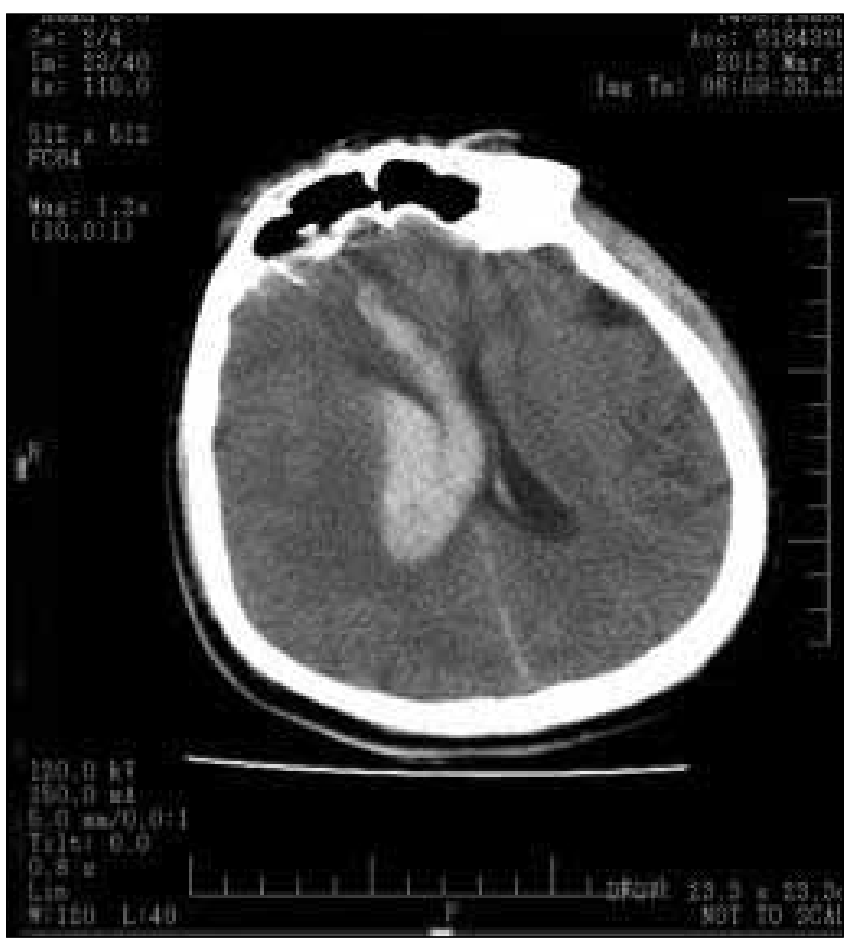

Figure 1: Non-contrast cranial tomography revealed an anterior interhemispheric bleeding with extension to all four ventricles (lateral ventricles).

angiography would have preferably been performed but the patient's condition did not allow this. No other tests related to an increased risk of stroke could be performed. An external ventricular drain was placed and the patient was taken to the intensive care unit but he failed to respond to maximal therapy and died.

\section{DISCUSSION}

The reasons of non-traumatic intracerebral hemorrhage can be categorised as hypertension, non-hypertensive gross structural vascular anomalies (AVM, aneurysm, MoyaMoya disease, amyloid angiopathy, etc.), intracranial neoplasms, cerebral venous thrombosis, infection and dysfunctional coagulopathy. Drug-induced intracerebral haemorrhages are related to anticoagulant thrombolytics, sympathomimetics, methamphetamines or cocaine $(1,7)$. Cases of intracerebral hemorrhages in relation to sildenafil use are being increasingly reported recently $(1,3,4,7,11)$.

Sildenafil is a selective phosphodiesterase-5 (PDE-5) enzyme inhibitor. With the inhibition of PDE-5, the amount of cyclicguanosine monophosphatase (cGMP) in the vascular smooth muscle cells in the corpus cavernosum increases, leading to a relaxation of muscles and vasodilatation (1). Studies have shown that the NO-c-GMP pathway leads to cerebral vasodilatation with a similar mechanism $(1,4)$. Alpsan et al. has shown that the effect of PDE-1 and PDE-2 on cerebral bleeding is affected by sildenafil. This increase in blood flow may increase the risk of intracranial haemorrhage (1).

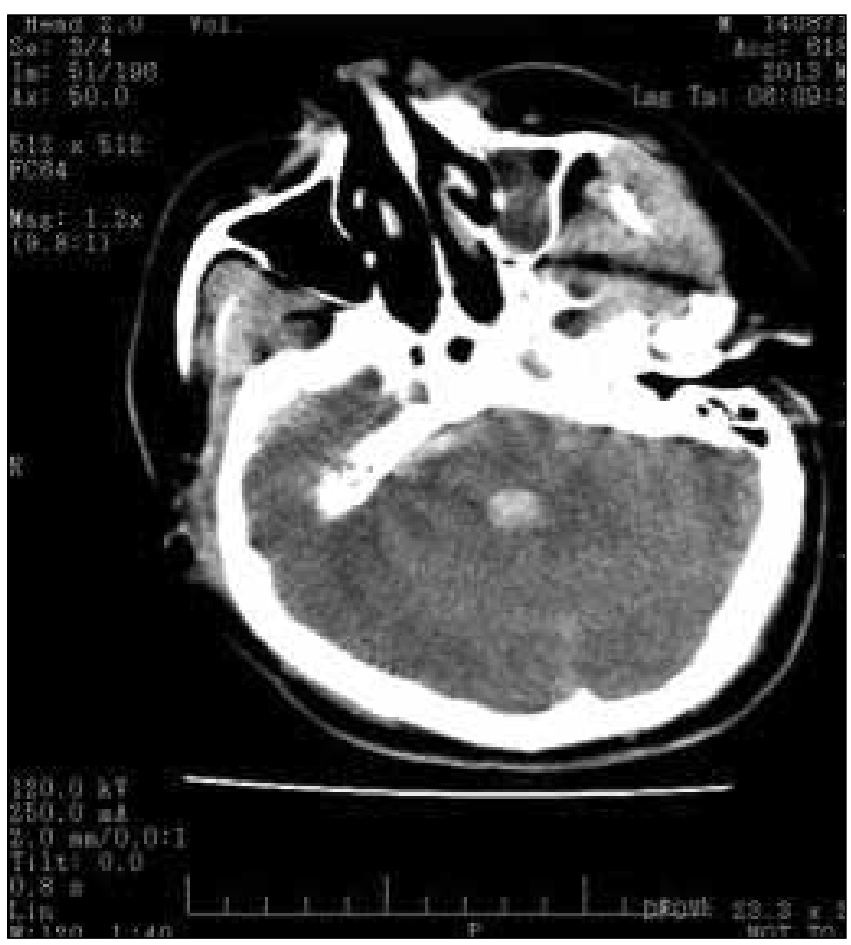

Figure 2: Non-contrast cranial tomography revealed an anterior interhemispheric bleeding with extension to all four ventricles (fourth ventricle).

The side effects of sildenafil are well known. There are side effects related to vascular structures such as headache, flushing, dizziness and nasal congestion (10).

Another result of the non-prescription use of the drug is usage in improper dose. The recommended starting dose of sildenafil should be $50 \mathrm{mg}$ and the maximum dose within 24 hours should be $100 \mathrm{mg}(10,11)$.

Sildenafil is the best selling drug in the global market for the treatment of male impotence (7). In addition to the use of prescription sildenafil, the non-prescription use of the drug is significantly high due to the ease in access to the drug without a prescription.

In this study; an intracerebral hemorrhage case due to the ingestion of alcohol with sildenafil where surgical treatment was not possible is presented. Although there are cases of subarachnoid haemorrhage and intracerebral hemorrhage caused by the use of sildenafil, there are few cases in the literature reporting intracerebral or subarachnoid hemorrhage associated with the use of sildenafil $(1,7,8,11$, 10).

Sildenafil is not reported to interact with ASA, antiacids and alcohol (6). It is difficult to understand the effects of alcohol ingestion in cases of intracranial hemorrhage caused by the combined ingestion of sildenafil with alcohol.There are reports in literature that point to a possible relationship between the ingestion of alcohol and spontaneous intracerebral 
hemorrhage $(2,6,9)$. There is no data suggesting an increase in the risk of spontaneous intracerebral hemorrhage due to combined ingestion of alcohol and sildenafil. However, our spontaneous intracerebral hemorrhage case after ingestion of alcohol and sildenafil indicates that this could be a harmful combination.

\section{CONCLUSION}

Although there is inadequate data to connect intracerebral hemorrhage to the combined use of alcohol ingestion and non-prescription use of sildenafil, caution should be exercised about drinking alcoholic beverages when using sildenafil as this may increase the risk of spontaneous intracerebral hemorrhage.

\section{REFERENCES}

1. Alpsan MH, Bebek N, Ciftci FD, Coban O, Bahar S, Tuncay R: Intracerebral hemorrhage associated with sildenafil use: Case report. J Neurol 255:932-933,2008

2. Ariesen MJ, Claus SP, Rinkel GJ, Algra A: Risk factors for intracerebral hemorrhage in the general population: A systematic review. Stroke 34(8):2060-2065,2003

3. Boyoun HS, Lee YJ, Yi HJ: Subarachnoid hemorrhage and intracerebral hematoma due to sildenafil ingestion in a young adult. J Korean Neurosurg Soc 47:210-212,2010

4. Buxton N, Flannery T, Wild D, Bassi S: Sildenafil (Viagra)induced spontaneous intracerebral haemorrhage. $\mathrm{Br} \mathrm{J}$ Neurosurg 15(4):347-349,2001
5. Casolla B, Dequatre-Ponchelle N, Rossi C, Hénon H, Leys D, Cordonnier C: Heavy alcohol intake and intracerebral hemorrhage: Characteristics and effect on outcome. Neurology 79(11):1109-1115,2012

6. Eardley I: The role of phosphodiesterase inhibitors in impotence. Exp Opin Invest Drugs 6:1803-1810,1997

7. Kaneria MV, Pagar S, Samant H, Yeole S, Patil S: Subarachnoid haemorrhage: Possibly caused by the illegitimate use of sildenafil citrate. J Assoc Physicians India 56:809-811,2008

8. Leppala JM, Virtamo J, Fogelholm R, et al: Different risk factors for different stroke subtypes: Association of blood pressure, cholesterol, and antioxidants. Stroke 30(12):2535-2540,1999

9. McHugh J, Cheek DJ: Nitric oxide and regulation of vascular tone; pharmacological and physiological consideration. Am J Crit (7):131-140,1998

10. O'Donnell MJ, Xavier D, Liu L, et al: Risk factors for ischaemic and intracerebral haemorrhagic stroke in 22 countries (the INTERSTROKE study): A case-control study. Lancet 376(9735):112-123,2010

11. Samada K, Shiraishi H, Aoyagi J, Momoi MY: Cerebral hemorrhage associated with sildenafil. Pediatr Cardiol 30:998999,2009

12. Zhang Y, Tuomilehto J, Jousilahti $P$, et al: Lifestyle factors on the risks of ischemic and hemorrhagic stroke. Arch Intern Med 171(20):1811-1818, 2011 